\title{
Clinical Analysis with Trauma Scoring in Blunt Thoracic Trauma
}

\author{
Künt Toraks Travmalarında Travma Skorlaması ile Klinik Analiz
}

\author{
Eray Cinar', Kubilay Inan², Ozgur Omer Yildiz ${ }^{3}$ \\ ${ }^{1}$ T.C. Ministry of Health, General Directorate of Emergency Health Services; ${ }^{2}$ Ankara City Hospital, Thoracic Surgery Clinic; ${ }^{3}$ Yildirim \\ Beyazit University, Faculty of Medicine, Thoracic Surgery Clinic, Ankara, Turkey
}

\begin{abstract}
Aim: Thoracic surgeons frequently encounter blunt thoracic traumas at the emergency ward. The clinical findings of such cases may require immediate action. The aim of the study is to discuss the efficiency of trauma scoring in the clinical course of blunt thoracic trauma.
\end{abstract}

Material and Method: Inpatients with blunt thoracic trauma who received care at the department of thoracic surgery between January 2017-2019 were analyzed. The cases were assessed based on gender, trauma type, surgical intervention, length of stay, and chest trauma scoring (CTS) (contusion, rib fracture, age) parameters.

Results: 111 (79.3\%) of the 140 patients assessed were male, and 29 (20.7\%) were female, and the average age was 49.3 (12-93). The patients were analyzed based on the chest trauma scoring calculated using the age, contusion, and rib fracture parameters. It was concluded that the trauma scoring varied between 2 and 7 (mean score $3.49 \pm 1.49$ ). There was a statistically significant relationship between the increasing age and the number of rib fractures $(p=0.004)$. An increased possibility of hemothorax and pneumothorax as the age increases was also observed ( $p=0.016, p=0.016$, respectively). It was determined that the higher the contusion rate was, the higher was the possibility of hemothorax $(p=0.03)$. It was observed that as the number of rib fractures increased, the possibility of hemothorax and pneumothorax increased and the relationship was statistically significant ( $p=0.009, p=0.018$, respectively). A statistically significant relationship between CTS score and pathologies of hemothorax and pneumothorax was identified ( $p=0.001, p=0.008$, respectively). However, no relationship between the CTS score and length of stay ( $p=0.612, p=0.612$, respectively) was observed.

Conclusion: The trauma scoring systems indeed act as an early warning system for the clinicians. However, the changing and developing health systems and many clinical parameters require modification in CTS, which is used to predict the clinical course of patients with isolated thoracic trauma, as in all trauma scores.

Key words: trauma; blunt thoracic trauma; trauma scoring

\section{ÖZET}

Amaç: Künt toraks travmaları acil servislerde gögüs cerrahlarının sık karșılaștıkları travma türüdür. Bu Klinik durumlar acil girișim gerektirecek düzeyde olabilir. Amacımı künt toraks travmalarının klinik gidișatında göğüs travma skorlama sisteminin etkinliğini tartıșmaktır.

Materyal ve Metot: Ocak 2017-2019 yılları arasında göğüs cerrahisi kliniğinde yatarak tedavi uygulanan künt toraks travmalı hastalar incelendi. Olgular yaș, cinsiyet, taravma türü, cerrahi müdahale yapılıp yapılmadığı, yatıș süreleri ve göğüs travma skorlaması (CTS) parametreleri (kontüzyon, kot fraktürü, yaș) ile değerlendirildi.

Bulgular: Değerlendirilen 140 hastanın 111'i (\%79,3) erkek, 29 'u $(\% 20,7)$ kadın olup yaș ortalaması 49,3 (12-93) olarak tespit edildi. Olgular yaș, kontüzyon ve kot fraktürü parametreleri kullanılarak hesaplanan CTS'ye göre göre analiz edildi. Travma skorlamasının 2 ile 7 arasında değiștiği (ort.3,49+1,49) görüldü. Artan yaș ile kaburga kırığı sayısı arasında istatistiksel olarak anlamlı bir ilișki olduğu görüldü $(p=0,004)$. Yaș arttıkça hemotoraks ve pnömotoraks olasılığının arttığı da gözlendi (sırasıyla $p=0,016$, $p=0,016)$. Kontüzyon oranı ne kadar yüksekse hemotoraks olasııı̆ının da o kadar yüksek olduğu belirlendi $(p=0,03)$. Kot fraktürü sayısı arttıkça hemotoraks ve pnömotoraks olasılığının arttığı ve ilișkinin istatistiksel olarak anlamlı olduğu görüldü (sırasıyla $p=0,009, p=0,018)$. CTS skoru ile hemotoraks ve pnömotoraks patolojileri arasında istatistiksel olarak anlamlı bir ilișki tespit edildi (sırasıyla $p=0,001, p=0,008)$. Ancak CTS skoru ile yatıș süresi ve komplikasyon arasında (sırasıyla $p=0,612, p=0,612$ ) bir ilișki gözlenmedi.

Sonuç: Travma skorlama sistemleri klinisyenlere yol gösteren için bir erken uyarı sistemi görevi görür. Bununla birlikte, değișen ve gelișen sağlık sistemleri ve birçok klinik parametre, tüm travma skorlarında olduğu gibi izole torasik travmalı hastaların klinik seyrini tahmin etmek için kullanılan CTS'ninde modifikasyonunu gerektirmektedir.

Anahtar kelimeler: travma; künt göğüs travması; travma skorlaması

IIletișim/Contact: Ozgur Omer Yildiz, Yildirim Beyazit Universitesi, Tip Fakultesi, Gogus Cerrahisi Klinigi, Ankara, Turkey • Tel:053381473 14 • E-mail:dr.ooyildiz@gmail.com • Geliș/Received: 1.03.2021 • Kabul/Accepted: 10.05.2021

ORCID: Eray Çınar, 0000-0002-4564-6097 • Kubilay Inan, 0000-0002-1409-4760 • Özgür Ömer Yildız, 0000-0001-7314-3131 


\section{Introduction}

Thoracic surgeons frequently encounter blunt thoracic traumas at the emergency ward. Thoracic trauma can happen due to various reasons such as falling from a height, traffic accidents, pounding, and animal attacks. Thoracic trauma can cause skin injury, rib fracture, sternum fracture, contusion, pneumothorax, and hemothorax. These clinical conditions may require various actions ranging from simply keeping the patient under observation to performing emergency surgeries.

Approaches based on protocols created using scoring in traumas were reported to shorten the length of stay and affect the treatment results positively ${ }^{1,2}$. Global multiple trauma scales such as "Injury Severity Score (ISS)" or "Trauma Injury Severity Score (TRISS)" are used in cases of multiple traumas ${ }^{3}$. However, it was observed that these scoring results might not be instructive in isolated thoracic trauma; therefore, a specialized thorax trauma scoring system was developed for thoracic trauma. Current thoracic trauma scoring systems can be listed as following: Wagner score, Abbreviated Injury Scale (AIS), Lung Injury Score, Pulmonary Contusion Score (PCS), RibScore, Thoracic Trauma Severity Score (TTSS), and Modified Early Warning Score (MEWS) ${ }^{4-9}$. Some ratings do not yet have an acceptable trauma score due to their difficult applicability and lack of predictive outcome. The studies conducted on thoracic scoring systems accept age, rib fracture, lung contusion, and bilateral trauma as the most important factors affecting the prognosis of a patient with thoracic trauma $^{10,11}$. These factors can help individually or all together to predict an outcome. Chest Trauma Scoring (CTS), which was developed by Pressley et al. ${ }^{11}$ and verified by Chen et al. ${ }^{1}$, includes assessing age, pulmonary contusion, and rib fracture parameters.

The treatment process and results were assessed using CTS analysis in patients with blunt thoracic trauma who were hospitalized in our clinic. Our aim is to share our results regarding the adequacy of the CTS system.

\section{Material and Method}

The inpatients with blunt thoracic trauma treated in the department of thoracic surgery between January 2017 - January 2019 were analyzed according to age, rib fracture, sternum fracture, clavicle fracture, hemothorax, pneumothorax, pulmonary contusion, pneumomediastinum, tube thoracostomy application, requiring surgery, complications, length of stay, and type of trauma.
The patients were treated according to the thoracic trauma treatment protocol. Appropriate approaches, including blood gas analysis, optimum analgesia (oral/IV/epidural/regional), respiratory support, and intensive care monitoring, including necessary interventions were used during the treatment and follow-up process.

The demographic parameters, anamnesis, vital parameters, and all necessary examinations, including chest radiography and computed thorax tomography (Thorax-CT), of the patients, were recorded while being examined at the emergency ward. CTS was used as the trauma scoring system. The CTS scoring system consists of four different parameters, and these are as follows: age, pulmonary contusion, number of rib fractures, and the existence of bilateral rib fractures. The number of rib fractures and pulmonary contusion areas were recorded using chest X-ray and thorax CT imaging methods (Table 1).

Each parameter was given a score, and the final CTS score, varying between $2-12$, was calculated using the given scores.

SPSS Version 23 was used for statistical analysis, and MS Excel program was used for graphics. The quantitative data were presented using the mean score, standard deviation (SD), median value, and the qualitative datawere presented in a frequency and percentage table. The relationship between different parameters were assessed using the Chi-square test. Spearman's Correlation Test was used in the correlation analysis. $p<0.05$ values were accepted as significant.

Table 1. Chest trauma scoring parameters and parameter scores

\begin{tabular}{lccc}
\hline Age score & Score & RIBFX Score & Score \\
\hline$<45$ & 1 & $<3$ RIBFX & 1 \\
$45-65$ & 2 & $3-5$ RIBFX & 2 \\
$>65$ & 3 & $>5$ RIBFX & 3 \\
Pulmonary contusion score & & Bilateral RIBFX & \\
None & 0 & None & 0 \\
Unilateral minor & 1 & Yes & 2 \\
Bilateral minor & 2 & & \\
Unilateral major & 3 & & \\
Bilateral major & 4 & & \\
\hline Final score 2-12. & & & \\
RiBFX, rib fractures. & &
\end{tabular}




\section{Results}

111 of the total 140 patients assessed were male (79.3\%), 29 were female (20.7\%), and the average age was 49.3 (12-93). 32 (22.9\%) of the patients were above the age of $65.38(27.1 \%)$ patients did not have any bone fractures. $14(10.0 \%)$ patients had one rib fracture, one patient had two rib fractures (0.7\%), and $71(50.7 \%)$ patients had three or more rib fractures. Four $(2.9 \%)$ patients had sternal fractures, two patients (1.4\%) had sternal fractures and one rib fracture, and two patients had clavicle fractures. Eight (5.7\%) patients had bilateral multiple rib fractures (five and more rib fractures). While 120 patients did not have any lung contusion, nine (6.4\%) patients had minimal contusion in one lung, and severe bilateral contusion was detected in 11 (7.9\%) patients. 13 (9.3\%) patients had massive hemothorax, 63 (45.0\%) patients had minimal hemothorax, and seven (5.0\%) patients had minimal bilateral hemothorax, and hemothorax was not detected in 57 (40.7\%) patients. The patients were also assessed in terms of pneumothorax, and minimal pneumothorax was observed in $22(15.7 \%)$ patients, $15 \%$ and above in $56(40.0 \%)$ patients, and bilateral minimal pneumothorax in three (2.1\%) patients. Pneumothorax was not observed in 59 (42.1\%) patients. Pneumomediastinum was present in two (1.4\%) patients, and it was not observed in 138 (98.6\%) patients. When the types of trauma were examined, it was seen that $50.7 \%$ of cases were due to traffic accidents and $35.0 \%$ due to falling (Table 2).

While tube thoracostomy was applied to only one hemothorax case out of 67 (47.9\%) patients and to the bilateral hemothorax of one $(0.7 \%)$ patient, it was not applied to $72(51.4 \%)$ patients. Thoracotomy bleeding control operation was carried out only for two (1.4\%) cases due to massive hemothorax. Other patients were followed clinically and radiologically. The length of

Table 2. Distribution and percentage of trauma types

\begin{tabular}{lcc}
\hline Trauma Type & $\mathrm{n}$ & $\%$ \\
\hline In-vehicle traffic accident & 51 & 36.4 \\
Non-vehicle traffic accident & 20 & 14.3 \\
Falling & 49 & 35.0 \\
Assault & 12 & 8.6 \\
Animal attack & 5 & 3.6 \\
Occupational accident & 3 & 2.1 \\
Total & 140 & 100.0 \\
\hline
\end{tabular}

stay varied between one and 23 days, and the mean value was four days. Complications were only observed in two $(1.4 \%)$ cases during the inpatient treatment. These complications were persistent air leaks in one case and pneumonia due to stasis of secretions in one patient.

According to CTS, the patients were re-analyzed based on age, contusion, and number of rib fractures. The trauma score varied between two and seven (mean value $3.49 \pm 1.49)$.

A statistically significant relationship was detected between the increasing age and the number of rib fractures in the comparative analysis of the variables $(\mathrm{p}=0.004)$. It was determined that as the age increased, the possibility of a rib fracture also increased. There was no statistically significant relationship between age, length of stay, and complications ( $\mathrm{p}=0.776, \mathrm{p}=0.780$, respectively). It was observed that CTS score increased with age, and the increase was statistically significant $(p<0.05)$. It was also determined that the possibility of hemothorax and pneumothorax increased with age ( $p=0.016, p=0.016$, respectively). A statistically significant relationship among gender, rib fracture, length of stay, and complications was not identified $(\mathrm{p}=0.458$, $\mathrm{p}=0.308, \mathrm{p}=0.470$, respectively).

Tube thoracostomy was applied to two patients with complications, and there was a statistically significant relationship between the two variables $(p=0.03)$. It was observed that the hospitalization period of the cases who underwent tube thoracostomy and operation was prolonged and was statistically significant $(\mathrm{p}<0.05, \mathrm{p}=0.02$, respectively). It was found that the higher the contusion rate, the higher the possibility of hemothorax was. $(p=0.03)$.

It was observed that as the number of rib fractures increased, the possibility of hemothorax and pneumothorax increased, and the relationship between these variables was statistically significant $(p=0.009$, $\mathrm{p}=0.018$, respectively).

A statistically significant relationship between CTS score and hemothorax and pneumothorax pathologies was identified $(\mathrm{p}=0.001, \mathrm{p}=0.008$, respectively). However, a relationship between the CTS score, length of stay, and complications were not identified $(\mathrm{p}=0.612$, $p=0.612$, respectively). A statistically significant relationship between the rib fracture and age in the CTS scoring system and CTS score $(\mathrm{p}<0.05)$ was identified, but a statistically significant relationship between contusion was not identified $(\mathrm{p}=0.08)$ (Table 3 ). 
Table 3. Statistical correlation (Spearman correlation) of the data in the study

\begin{tabular}{lccccccccccc}
\hline CTS & Age & Cont & Rib frx & Gender & Hemx & Pnx & Length of stay & Op & Compl & Tube & Trauma type \\
\hline Correlation coefficient & $0.762^{* *}$ & 0.146 & $0.602^{* *}$ & 0.164 & $0.275^{* *}$ & $-0.223^{* *}$ & 0.043 & -0.074 & 0.043 & -0.165 & -0.064 \\
Sig. (2-tailed) & 0.0001 & 0.084 & 0.0001 & 0.052 & 0.001 & 0.008 & 0.612 & 0.382 & 0.612 & 0.052 & 0.451 \\
N & 140 & 140 & 140 & 140 & 140 & 140 & 140 & 140 & 140 & 140 & 140 \\
\hline
\end{tabular}

Cont, contusion; frx, fracture; Hemx, hemothorax; Pnx, pneumothorax; 0p, operation; Compl, complications; Tube, tube thoracostomy.

\section{Discussion}

Traumas are among the leading causes of death. The mortality rate of cases that apply to hospitals due to severe chest trauma is between $20-25 \%^{12,13}$. $70 \%$ of thoracic traumas are blunt, and $30 \%$ are penetrating thoracic injuries. Thoracic surgeons most frequently encounter blunt chest trauma in the emergency ward. The severity and type of trauma vary according to the age, lifestyle, socio-cultural and economic level of the patient, as well as the country and geography in which the patient lives ${ }^{14}$.

Symptoms and clinical conditions caused by blunt thoracic trauma are generally ribs, sternum, clavicle fractures, hemothorax, pneumothorax, diaphragmatic ruptures, cardiac injury, pneumomediastinum, and parenchymal lung injury (laceration, contusion). The most common finding is rib fracture ${ }^{15}$. This rate was around $70 \%$ in our study, and the ratio of multiple rib fractures was around $67.8 \%$.

The most common intrathoracic trauma complications are hemothorax, pneumothorax, and hemopneumothorax. Similarly, this rate was identified respectively as $59.2 \%, 55.7 \%$, and $30 \%$. The pulmonary contusion, which we frequently observe during the posttraumatic period, may cause severe conditions, such as ARDS ${ }^{15,16}$. The pulmonary contusion rate in our study was determined as $14.2 \%$.

Tube thoracostomy is an adequate surgical intervention in the majority of pleural complications ${ }^{15}$. In our study, the tube thoracostomy rate was identified as $48.5 \%$, and the operation rate was calculated as $1.4 \%$; in addition, this rate is higher in younger patients than elderly patients. Over the years, the developments in healthcare services, easy access to healthcare services, increasing awareness of people, and socio-cultural-economic developments have led to a noticeable decrease in mortality, morbidity, and surgical intervention rates in trauma patients.
Diaphragm injuries occur in approximately 3\% of all abdominal injuries. Injury of the isolated diaphragm is rare and is associated with other organ injuries in 80$100 \%$ of the cases ${ }^{17,18}$. The patients were not diagnosed with diaphragm injuries in our study.

There is not a standard method to assess the severity of blunt thoracic trauma. Hence, scoring systems that can support grouping patients in risk groups are needed.

Many scoring methods are described to presume the clinical progression of trauma patients. CTS, which is used mainly in isolated thoracic trauma cases, has been used in the literature to assess the clinical progression of patients with thoracic trauma, and it has been suggested that a score of $\geq 5$ indicates high complications and mortality rates, and clinical worsening ${ }^{1,10} .140$ patients with thoracic trauma were assessed using CTS, and their clinical progressions were presumed. The results were compared with the literature. Cases were assessed using factors such as age, rib fracture, number of rib fractures, flail chest development, bilateral injuries, pre-existing comorbidities, and post-injury pneumonia development, and scoring systems were used to identify high-risk patients ${ }^{5,11,19,20}$.

There is a statistically significant relationship, $p=0.244$, between age and rib fracture in our study. Therefore, as age increases, CTS scores increase, and as the severity of the rib fracture increases, CTS scores increase as well.

In trauma patients, the length of stay is decreased by using treatment protocols and medical interventions created with the help of the scoring systems ${ }^{1,2}$. In our study, a significant relationship between CTS score and length of stay is not identified $(p=0.043)$. The mean score of the length of stay according to age and gender is three to four days, and there is not a significant relationship between these two variables. In our study, a significant relationship between the CTS score and operation was not identified. 
Chen et al. ${ }^{1}$ put forward that the CTS score being $\geq 5$ in this scoring system may indicate adverse results such as complications and mortality in thoracic trauma patients. Pressley ${ }^{11}$ linked patients with high scores to pulmonary complications and stated that their need for intubation is higher.

A significant relationship between CTS score and complications was not identified in our study. However, a positive correlation between CTS score and hemothorax was identified. CTS score increases as the severity of hemothorax increases. In our study, also, a negative correlation between CTS and pneumothorax was identified. CTS score decreases as the severity of pneumothorax increases. There is not a significant relationship between CTS score and tube thoracostomy $(\mathrm{p}=0.052)$.

Generally, it is thought that elderly patients will have worse clinical findings and progression after blunt trauma. However, our study shows that elderly patients do not differ in clinical terms from younger patients.

Our study shows that in traumatic hemothorax, pneumothorax, and hemopneumothorax cases, small operations and clinical, radiologic follow-up are sufficient for most patients.

When the CTS scores and clinical progression of the patients were compared and analyzed, results that were clearly defined in the literature were not obtained. Increases in CTS scores did not cause a relationship between poor prognosis and complications, as stated in all patients. Even though old age is a risk factor, the type and severity of traumas experienced by the elderly are different from the younger patients. The lifestyle of younger patients also differentiates the severity of the trauma they are exposed to compared to the elderly. The severity of the experienced trauma increases the rate of complications to develop and CTS score. Even though multiple organ injuries are not within the scope of this study, younger patients experience more severe blunt trauma types than the elderly. We believe that the social and cultural conditions and the abilities of self-care affect the complications and recovery period. The conditions of the clinic where the patients are being treated also affect factors such as recovery, length of stay, and complications. Although the studies are being carried out by accepting these conditions as optimum, the available trauma scoring systems are not enough on their own to identify the prognosis, and they can only serve as a pre-assessment, estimation, and an alert.
Other factors, such as comorbidities, affect the clinical progression of the patients, and these factors could be included in the scoring systems.

\section{Conclusion}

It is a generally accepted fact that trauma scoring systems serve as an early warning system for clinicians. Our study observed that the increase in CTS score did not create a poor prognosis and increased complication rates. Many clinical approaches and parameters affect the development of complications and recovery. In addition to a close follow-up and good health care, the scoring systems may warn the clinicians about which trauma patients should be followed more carefully. Like any trauma scoring, the CTS must be updated over time.

\section{References}

1. Chen J, Jeremitsky E, Philp F, Fry W, Smith RS. A chest trauma scoring system to predict outcomes. Surgery 2014;156(4):98894.

2. Pape HC, Remmers D, Rice J, Ebisch M, Krettek C, Tscherne H. Appraisal of early evaluation of blunt chest trauma: Development of a standardized scoring system for initial clinical decision making. J Trauma 2000;49(3):496-504.

3. Valderrama-Molina CO, Giraldo N, Constain A, Puerta A, Restrepo C, León A, et al. Validation of trauma scales: ISS, NISS, TRS and TRISS for predicting mortality in a Colombian population. Eur J Orthop Surg Traumatol 2017;27(2):213-20.

4. Ekpe EE, Eyo C. Determinants of mortality in chest trauma patients. Niger J Surg 2014;20(1):30-4.

5. Hildebrand F, GriensvenMv, Garapati R, Krettek C, Pape HC. Diagnostics and scoring in blunt chest trauma. Eur J Trauma 2002;28(3):157-67.

6. Wagner RB, Jamieson PM. Pulmonary contusion. Evaluation and classification of computed tomography. Surg Clin North Am 1989;69(1):31-4.

7. Tybursky JG, Collinge JD, Wilson RF, Eachempati SR. Pulmonary contusion: Quantifying the lesions on chest $\mathrm{x}$-ray films and the factors affecting prognosis. J Trauma 1999;46(5):833-8.

8. Civil ID, Schwab CW. The Abbreviated Injury Scale, 1985 revision: A condensed chart for clinical use. J Trauma 1988;28(1):87-90.

9. Chapman BC, Herbert B, Rodil M, Salotto J, Stovall RT, Biffl W, et al. RibScore: A novel radiographic score based on fracture pattern that predicts pneumonia, respiratory failure, and tracheostomy. J Trauma Acute Care Surg 2014;80(1):95-101.

10. Perna V, Morera R. Prognostic factors in chest traumas: A prospective study of 500 patients. Cir Esp 2010;87(3):145-70. 
11. Pressley CM, Fry WR, Philp AS, Berry SD, Smith RS. Predicting outcome of patients with chest wall injury. Am J Surg 2012;204(6):910-4.

12. Battistella FD, Benfield JR. Blunt and penetrating injuries of the chest wall, pleura, and lungs. In: Shields TW. General Thoracic Surgery. Fifth ed. Philadelphia: Williams and Wilkins; 2000;815-63.

13. Lo Cicero I, Mattox KL. Epidemiology of chest trauma. Surg Clin North Am 1989;69(1):15-9.

14. Çakan A, Yuncu G, Olgaç G, Alar T, Sevinc S, Ors Kaya S et al. Chest traumas: Analysis of 987 cases. Ulus Travma Derg 2001;7(4):236-41.

15. Kahraman C, Akcal Y, Emirogulları N, Elbeyli L, Sozuer E, Tasdemir K et al. Blunt thoracic trauma. Erciyes Tip Dergisi $1995 ; 17: 318-24$
16. Dee PM. The Radiology of Chest Trauma. Rad Clin North Am 1992;30:291-306.

17. Asensio JA, Demetriades D, Rodriguez A. Injury to the diaphragm. In Mattox KL, Feliciano DV, Moore EE, ed. Trauma 4th ed. New York: McGraw-Hill; 2000:603-31.

18. Meteroglu F, Eren TS. Traumatic Diaphragmatic Ruptures. Toraks Cerrahisi Bul 2014;4(4):259-65.

19. Curtis K, Asha SE, Unsworth A, Lam M, Goldsmith H, Langcake M, et al. ChIP. An early activation protocol for isolated blunt chest injury improves outcomes, a retrospective cohort study. Australas Emerg Nurs J 2014;19(3):127-32.

20. Grubmüller M, Kerschbaum M, Diepold E, Angerpointner K, Nerlich M, Ernstberger A. Severe thoracic trauma - Still an independent predictor for death in multiple injured patients? Scand J Trauma Resusc Emerg Med 2018;26(6):1-8. 